\title{
PENGEMBANGAN MEDIA PEMBELAJARAN PENDIDIKAN JASMANI OLAHRAGA DAN KESEHATAN BERBASIS KOMPUTER UNTUK SMA
}

\section{COMPUTER BASED LEARNING MEDIA DEVELOPMENT OF PHYSICAL EDUCATION FOR HIGH SCHOOLS}

\author{
Suci Cahyati, Wawan S. Suherman \\ - , Universitas Negeri Yogyakarta \\ suci_cahyati17@yahoo.co.id,wawansundawan@uny.ac.id
}

\begin{abstract}
Abstrak
Penelitian ini bertujuan untuk menghasilkan produk berupa CD pembelajaran pendidikan jasmani olahraga dan kesehatan berbasis komputer untuk SMA yang valid dan efektif. Penelitian ini menggunakan metode Research and Development (R\&D). Media yang dikembangkan memuat materi tentang HIV/AIDS. Pengembangan media pembelajaran ini menggunakan software Adobe Flash Cs 3 Professional. Media yang telah dikembangkan melalui dua tahap penelitiannya itu validasi ahli dan uji coba lapangan. Berdasarkan validasi ahli dan uji coba lapangan hasil penelitian menunjukkan produk termasuk kriteria "Sangat baik" dengan rerata skor 4,25. Hasil tes siswa mengalami peningkatan dari rerata skor pretest 5,53 dan rerata skor posttest 7,56. Berdasarkan hasil tes tersebut dapat disimpulkan bahwa media pembelajaran pendidikan jasmani olahraga dan kesehatan efektif digunakan dalam pembelajaran di SMA.
\end{abstract}

Kata kunci: Pengembangan media, penjasorkes, SMA

\begin{abstract}
This research aims to produce a CD computer based learning media of Physical Education for high schools which is validated. This research used Research and Development $(R \& D)$. Adobe Flash Cs3 Professional software was used to develop this media. Media were developed containing material about HIV/AIDS. This research included two stages: expert validation phase and the test phase. The quality of media from validation and o trial is "very good" with average 4.25. Test results from test show that score increased with average score for pret.est is 5.53 and average score for posttest is 7.56. Based on the test results from main field trial show, the media is effective used for learning.
\end{abstract}

Keywords: Media development, physical education, high school 


\section{Pendahuluan}

HIV/AIDS merupakan ancaman besar bagi remaja yang sebagian besar adalah kalangan pelajar. Berdasarkan data statistik kasus HIV/AIDS di Indonesia dilaporkan sampai dengan Maret 2013 oleh Ditjen PP dan PL Kemenkes RI, secara kumulatif HIV \& AIDS pada tanggal 1 April 1987 s.d. 31 Maret 2013 dengan jumlah total HIV 103.759 orang, jumlah total AIDS 43.347 dan kematian 8.288 orang. Jumlah kumulatif kasus AIDS menurut golongan umur < 1-19 tahun berjumlah 2676 orang. Cates (1989) menyatakan bahwa pendidikan sangat penting untuk menghentikan penularan Human Immunodeficiency Virus (HIV) dan epidemi AIDS (acquired immunodeficiency syndrome) sampai vaksin dan atau terapi kuratif tersedia. Pendidikan merupakan suatu kegiatan belajar dan pembelajaran.

Sudjana (2001, p.28) menyatakan bahwa belajar adalah suatu proses yang ditandai dengan adanya perubahan pada diri seseorang. Belajar menurut Morgan (Suprijono, 2009, p.3) adalah perubahan perilaku yang bersifat permanen sebagai hasil dari pengalaman. Salah satu pertanda bahwa seseorang telah belajar sesuatu adalah adanya perubahan tingkah laku dalam dirinya. Perubahan tingkah laku tersebut menyangkut baik perubahan yang bersifat pengetahuan (kognitif), keterampilan (psikomotor) maupun yang menyangkut nilai dan sikap (afektif). Belajar tidak hanya meliputi mata pelajaran, tetapi juga penguasaan, kebiasaan, persepsi, kesenangan, kompetensi, penyesuaian sosial, bermacam-macam keterampilan, dan cita-cita.

Pembelajaran adalah proses interaksi antara peserta didik dengan lingkungannya, sehingga terjadi perubahan perilaku ke arah yang lebih baik. Sukintaka (2001, p.29) menyatakan bahwa pembelajaran mengandung pengertian bagaimana para guru mengajarkan sesuatu kepada peserta didik, di samping itu juga terjadi peristiwa bagaimana peserta didik mempelajarinya.

Pendidikan Jasmani Olahraga dan Kesehatan dalam kurikulum 2013 merupakan salah satu mata pelajaran wajib di SMA yang diikuti oleh seluruh peserta didik. Dalam kurikulum 2013, materi kesehatan tentang HIV/ AIDS tercantum sebagai kompetensi dasar 3.11. Hasil observasi dan wawancara dengan beberapa guru SMA menunjukkan bahwa proses pembelajaran Penjasorkes lebih banyak meng- arah pada pengembangan kemampuan psikomotorik dan kurang memperhatikan pengembangan aspek kognitif. Ketidakseimbangan proses pembelajaran tersebut terjadi karena kurangnya kesadaran dan minat guru Penjasorkes dalam mengajarkan materi teori pendidikan kesehatan. Pada umumnya, guru mata pelajaran Penjasorkes menyampaikan materi teori hanya pada waktu tertentu saja seperti ketika bulan Ramadhan. Selain itu, masih minimnya pemahaman dan penggunaan sumber belajar yang berbasis teknologi dalam membantu proses pembelajaran Penjasorkes.

Di era global dan digital saat ini, perkembangan Ilmu pengetahuan dan teknologi informasi berkembang sangat pesat, hal tersebut telah merasuki seluruh aspek kehidupan sosial, ekonomi, politik, budaya dan pendidikan. Di bidang pendidikan, fokus pengajaran sekarang ini adalah bagaimana penyampaian pelajaran bisa efektif dengan menggunakan teknologi pembelajaran (Instructional Technology). Media pendidikan sebagai produk dari teknologi pembelajaran semakin bervariasi mulai dari yang sederhana hingga yang canggih. Media cetak dan elektronik pun pada dasarnya memiliki potensi untuk menunjang kegiatan pendidikan dan pembelajaran.

Rahardi (2003, p.9) menyatakan bahwa media adalah saluran komunikasi yang digunakan untuk menyampaikan pesan antara sumber dengan penerima pesan. Djamarah dan Zain (2002, p.136) berpendapat bahwa media adalah wahana menjelaskan apabila media adalah sumber belajar maka secara luas media dapat diartikan sebagai manusia, benda, ataupun peristiwa yang memungkinkan anak didik memperoleh pengetahuan dan keterampilan. Sadiman dkk. (2006, p.182) mengemukakan bahwa media pembelajaran yang dipilih haruslah sesuai dengan tiga hal ialah tujuan, materi, dan strategi pembelajaranya.

Penggunaan komputer dalam pembelajaran membantu tercapainya tujuan pembelajaran dikarenakan siswa dapat langsung berinteraksi dengan materi yang diajar. Lee dan Owens (2004, p.118) menyatakan multimedia yang berkualitas memiliki tema yang seharusnya berhubungan dengan pemecahan masalah, batasan interaksi dan umpan balik, batasan perlakuan video dan audio, standar desain grafis, dan mengatur animasi dan efek khusus digunakan untuk mendukung tujuan pembelajaran.

Pemanfaatan media pembelajaran berbasis komputer dengan Adobe Flash Cs3 Pro- 
fessional adalah pemanfaatan program aplikasi Adobe Flash Cs3 Professional sebagai alat untuk membuat, merancang, dan menjalankan media. Program aplikasi Adobe Flash Cs3 Professional merupakan salah satu software yang dapat dirancang khusus. Program ini dapat menampilkan program multimedia yang menarik, mudah dalam pembuatan dan penyimpanan, mudah dalam penggunaan dan relatif murah. Penggunaan Adobe Flash Cs3 Professional sebagai software untuk pembuatan media pembelajaran interaktif berdasarkan pada beberapa kelebihan yang dimilikinya (Sutopo, 2003, p.60). Walaupun tidak sulit bagi guru untuk mendesain media pembelajarannya, namun selama ini banyak guru kurang memanfaatkan media-media pembelajaran khususnya yang berbasis komputer. Agar materi dapat dipahami dan menarik bagi siswa, dan guru dapat mengembangkan materi ajar maka peneliti mencoba mengangkat permasalahan pemanfaatan Adobe Flash Cs3 Professional.

Berangkat dari permasalahan tersebut, peneliti mencoba untuk melakukan pengembangan media pembelajaran berbasis komputer yang dirancang dengan Adobe Flash Cs3 Professional materi HIV/AIDS mata pelajaran Penjasorkes yang valid dan efektif. Adapun tujuan pengembangan penelitian ini untuk menghasilkan sebuah media pembelajaran berbasis komputer mata pelajaran Penjasorkes materi HIV/ AIDS yang tervalidasi dan efektif digunakan dalam pembelajaran di sekolah. Dari pengembangan ini guru memperoleh dan memiliki sumber belajar baru dan dapat dijadikan sumber belajar mandiri bagi siswa.

\section{Metode}

Penelitian ini merupakan penelitian dan pengembangan (Research and Development) sesuai dengan pendapat Borg and Gall (1983, p.772) bahwa penelitian dan pengembangan adalah suatu proses yang digunakan untuk mengembangkan atau memvalidasi produk-produk yang digunakan dalam pendidikan dan pembelajaran. Untuk mendapatkan media yang sesuai dengan tujuan, maka penelitian ini mengadopsi prosedur pengembangan Borg \& Gall (1983, pp.774-786) yang disederhanakan agar lebih mudah dipahami.

\section{Prosedur}

Prosedur penelitian dan pengembangan yang akan dilalui dalam penelitian ini sebagai berikut: (1) pendahuluan dan perencanaan, me- rupakan langkah awal memulai pengembangan yaitu menentukan mata pelajaran, melakukan identifikasi kebutuhan, dan menentukan materi; (2) pengembangan desain pembelajaran, meliputi: menentukan tujuan pembelajaran yaitu kompetensi inti, melakukan analisis pembelajaran, mengidentifikasi perilaku dan karakteristik siswa, merumuskan kompetensi dasar, mengembangkan materi pembelajaran, mengembangkan butir tes, menyusun strategi pembelajaran, menetapkan evaluasi/penilaian; (3) pengembangan desain media, meliputi: pembuatan flowchart view dan penulisan naskah, pengumpulan bahan-bahan, proses pembuatan produk menggunakan software Adobe Flash Cs3 Professional; (4) Expert Judgement, media yang dikembangkan divalidasi oleh dua ahli materi dan satu ahli media. Data hasil validasi ahli kemudian dianalisis dan dilakukan perbaikan terhadap media sesuai saran; (5) Desain uji coba, ada tiga tahapan yakni: uji coba lapangan awal, uji coba lapangan utama, dan uji operasional, dengan penjelasan sebagai berikut: (a) uji coba lapangan awal, data diambil dari siswa kelas XI yang melibatkan 3 sekolah yakni SMA Negeri 1, SMA Negeri 2 dan SMA Negeri 3 Yogyakarta dengan jumlah subjek 15 siswa. (b) uji coba lapangan utama, data diambil dari siswa kelas XI yang melibatkan 6 sekolah yakni SMA Negeri 4, SMA Negeri 5, SMA Negeri 6, SMA Negeri 7, SMA Negeri 8, dan SMA Negeri 9 Yogyakarta dengan jumlah subjek 30 siswa. Pada tahap ini data yang diperoleh hasil dari tes/penilaian tentang prestasi belajar siswa yang dilakukan sebelum dan sesudah proses pembelajaran. Uji coba lapangan utama ini bertujuan untuk mengetahui efektifitas media yang dikembangkan. Uji coba ini menggunakan metode one-group pretest-posttest design.(c) uji operasional, melibatkan seluruh SMA Negeri se Kotamadya Yogyakarta yang berjumlah $11 \mathrm{Se}-$ kolah dengan jumlah subjek 55 siswa. Data dikumpulkan menggunakan angket. Selanjutnya data yang dihasilkan kemudian dianalisis, hasil analisis dijadikan bahan untuk perbaikan media dan melakukan revisi akhir; (6) hasil akhir Produk, berupa CD yang telah diketahui validitas dan efektifitasnya; (7) diseminasi, penyebarluasan hasil penelitian ini dilakukan melalui jurnal PPs UNY dan pemberian CD ke SMA Negeri se-Kotamadya Yogyakarta.

\section{Subjek Penelitian}

Penelitian dan pengembangan ini melibatkan 2 ahli materi dan 1 ahli media. Dua ahli 
materi yang dipilih sebagai validator media yang dikembangkan terdiri dari dosen dan guru. Ahli media yang dipilih merupakan ahli multimedia yang merupakan dosen dan guru besar sekaligus Kaprodi Teknologi Pembelajaran di PPs UNY.

Uji coba instrumen angket dan tes melibatkan satu sekolah yakni MAN Yogyakarta III berjumlah 30 siswa kelas XI. Uji coba lapangan awal melibatkan 3 Sekolah yakni SMA Negeri 1, SMA Negeri 2 dan SMA Negeri 3 Yogyakarta dengan jumlah subjek 15 siswa. Uji coba lapangan utama melibatkan 6 sekolah yakni SMA Negeri 4, SMA Negeri 5, SMA Negeri 6, SMA Negeri 7, SMA Negeri 8, dan SMA Negeri 9 Yogyakarta dengan jumlah subjek 30 siswa. Uji coba operasional, melibatkan seluruh SMA Negeri se-Kotamadya Yogyakarta yang berjumlah 11 sekolah dengan jumlah subjek 55 siswa. Siswa yang terlibat dalam penelitian ini adalah siswa kelas XI.

Intrumen, dan Teknik Pengumpulan Data

Instrumen pengumpulan data yang digunakan dalam penelitian pengembangan ini berupa angket dan tes soal pilihan ganda. Angket yang digunakan dalam penelitian pengembangan ini, bertujuan untuk menggali tanggapan atau penilaian dari ahli maupun siswa atas media yang dikembangkan. Intrumen tes untuk siswa bertujuan untuk mengetahui tingkat efektifitas media yang dikembangkan.

Teknik Analisis Data

Analisis data angket. Teknik analisis data kuantitatif dalam penelitian ini menggunakan analisis statistik deskriptif, yang berupa pernyataan sangat kurang, kurang, cukup baik, baik dan sangat baik yang diubah menjadi data kuantitatif dengan skala 5 yaitu dengan penskoran dari angka $1 \mathrm{~s} / \mathrm{d}$ 5. Langkah-langkah dalam analisis data antara lain: (a) mengumpulkan data kasar, (b) pemberian skor, (c) skor yang diperoleh kemudian dikonversikan menjadi ni- lai dengan skala 5. Data yang sudah dikonversi selanjutnya dianalisis. Data kualitatif berupa kritik dan saran yang dikemukakan oleh ahli media, ahli materi dan siswa kemudian dihimpun untuk perbaikan. Analisis data angket lebih jelas dapat dilihat pada tabel berikut:

Tabel 1. Kriteria Penilaian

\begin{tabular}{ccc}
\hline \multirow{2}{*}{ Kriteria } & \multicolumn{2}{c}{ Skor } \\
\cline { 2 - 3 } & Rumus & Perhitungan \\
\hline Sangat & $\mathrm{X}>\mathrm{Xi}+1,8 \mathrm{Sbi}$ & $\mathrm{X}>4,21$ \\
Baik & $\mathrm{Xi}+0,6 \mathrm{Sbi}<\mathrm{X} \leq \mathrm{Xi}+$ & $3,40<\mathrm{X} \leq$ \\
Baik & $1,8 \mathrm{Sbi}$ & 4,21 \\
Cukup & $\mathrm{Xi}-0,6 \mathrm{Sbi}<\mathrm{X} \leq \mathrm{Xi}+$ & $2,60<\mathrm{X} \leq$ \\
Baik & $1,8 \mathrm{Sbi}$ & 3,40 \\
Kurang & $\mathrm{Xi}-0,6 \mathrm{Sbi}<\mathrm{X} \leq \mathrm{Xi}-$ & $1,79<\mathrm{X} \leq$ \\
Sangat & $1,8 \mathrm{Sbi}$ & 2,60 \\
Kurang & $\mathrm{X} \leq \mathrm{Xi}-1,8 \mathrm{Sbi}$ & $\mathrm{X} \leq 1,79$ \\
\hline
\end{tabular}

Analisis data tes. Setelah dilaksanakan pretest dan posttest diperoleh skor dari masingmasing siswa kemudian dicari nilai rata-ratanya kemudian dibandingkan. Dari hasil perhitungan dan perbandingan nilai rata-rata tersebut dapat diketahui apakah ada peningkatan terhadap penguasaan siswa terhadap materi. Jika terjadi peningkatan nilai rata-rata antara pretest dan posttest dapat disimpulkan bahwa media yang diberikan efektif digunakan. Begitupun sebaliknya, jika media tidak memberikan peningkatan terhadap penguasaan materi maka rata-rata antara pretest dan posttest mengalami penurunan.

\section{Hasil Penelitian dan Pembahasan}

Media setelah melalui tahap pendahuluan, perencanaan, dan pengembangan desain, tahap selanjutnya adalah pengembangan media. Sebelum melakukan pengembangan media, langkah awal yang dilakukan adalah membuat flowchart. Untuk lebih jelas flowchart dapat dilihat pada gambar berikut. 


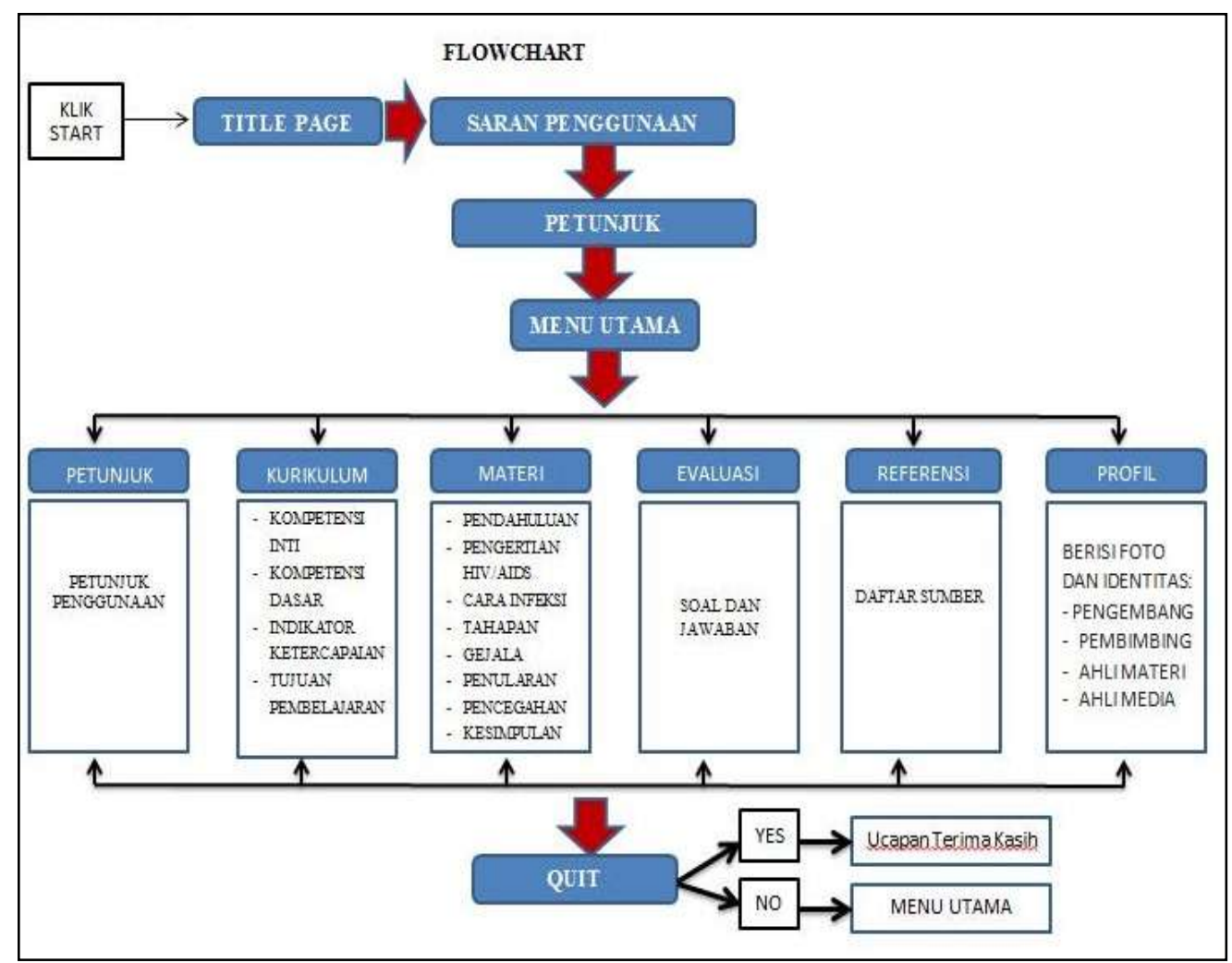

Gambar 1. Flowchart View

Setelah melalui tahap pengembangan selanjutnyadilakukan penelitian yang terdiri dari dua tahap yakni tahap validasi dan tahap uji coba. Validator pada tahap validasi terdiri dari 3 ahli yakni 2 ahli materi dan 1 ahli media. Data hasil validasi ahli dikumpulkan menggunakan insturmen angket.

Penilaian produk oleh ahli materi menunjukkan kualitas materi dalam media. Berikut ini tabel tentang kualitas produk hasil validasi ahli materi.

Tabel 2. Kualitas Produk oleh Ahli Materi

\begin{tabular}{|c|c|c|c|c|}
\hline No & $\begin{array}{c}\text { Aspek } \\
\text { Penilaian }\end{array}$ & $\begin{array}{c}\text { Ahli } \\
\text { Materi } \\
\text { I }\end{array}$ & $\begin{array}{c}\text { Ahli } \\
\text { Materi } \\
\text { II }\end{array}$ & Rerata \\
\hline 1 & Kualitas & & & \\
\hline & $\begin{array}{l}\text { Materi } \\
\text { Pembelajaran }\end{array}$ & 4,30 & 4,90 & 4,58 \\
\hline 2 & Aspek Isi & 4,63 & 5,00 & 4,81 \\
\hline \multicolumn{4}{|c|}{ Rata-rata } & 4,69 \\
\hline & \multicolumn{3}{|c|}{ Kriteria } & $\begin{array}{c}\text { Sangat } \\
\text { Baik }\end{array}$ \\
\hline
\end{tabular}

Berdasarkan data pada tabel 2 dapat disimpulkan bahwa kualitas media termasuk kriteria "Sangat Baik" dengan rerata 4,69. Berikut ini gambar tentang kualitas produk hasil validasi ahli materi.

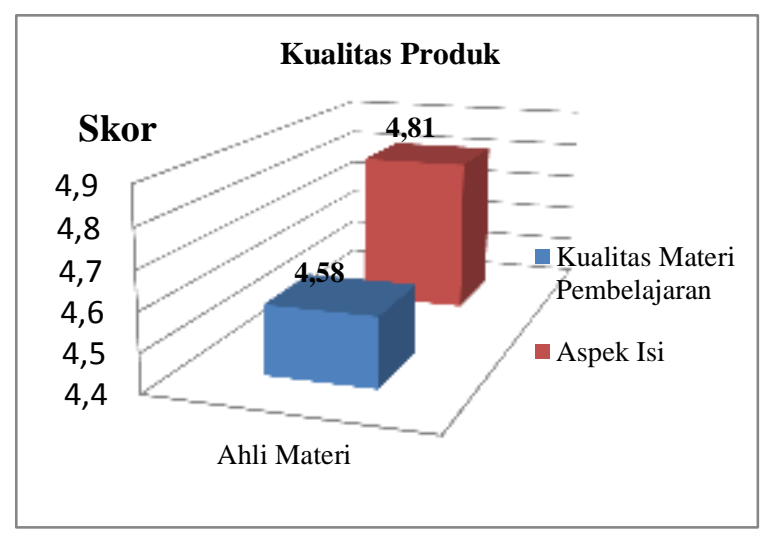

Gambar 2. Kualitas Produk Hasil Validasi Ahli Materi

Penilaian ahli media dan rerata skor yang diberikan untuk aspek tampilan dan aspek pemrograman. Adapun kualitas produk hasil validasi ahli media sebagai berikut.

Tabel 3. Penilaian Produk Validasi Ahli Media

\begin{tabular}{cccc}
\hline No & $\begin{array}{c}\text { Aspek } \\
\text { Penilaian }\end{array}$ & Tahap I & Tahap II \\
\hline 1 & Tampilan & 3,78 & 4,04 \\
2 & Pemrograman & 3,20 & 4,00 \\
Rerata & $\mathbf{3 , 4 9}$ & $\mathbf{4 , 0 2}$ \\
Kriteria & Baik & Baik \\
\hline
\end{tabular}

Kualitas produk hasil validasi ahli media tahap I termasuk "Baik" dengan rata-rata 
3,49 sedangkan pada tahap II media termasuk "Baik" dengan rata-rata 4,02. Berikut ini gambar kualitas produk hasil validasi ahli media. Berikut ini gambar tentang kualitas produk hasil validasi ahli media.

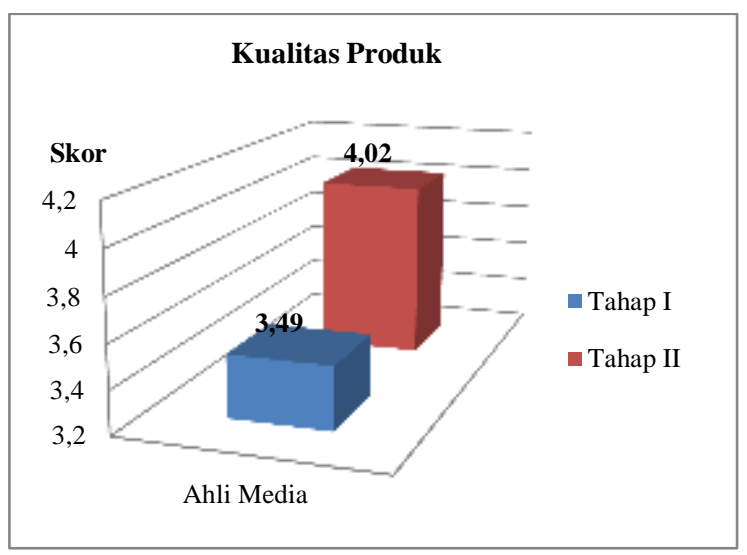

Gambar 3. Kualitas Produk Hasil Validasi Ahli Media

Penilaian siswa hasil uji coba lapangan awal dan rerata skor yang diberikan untuk aspek tampilan, isi dan aspek pembelajaran lebih jelas dapat dilihat pada tabel dan gambar berikut.

Tabel 4. Penilaian Uji CobaLapangan Awal

\begin{tabular}{clc}
\hline No & \multicolumn{1}{c}{ Aspek Penilaian } & Rerata \\
\hline 1 & Tampilan & 3,78 \\
2 & Isi & 3,97 \\
3 & Pembelajaran & 3,87 \\
Rata-rata & Skor & $\mathbf{3 , 8 7}$ \\
Kriteria & Baik \\
\hline
\end{tabular}

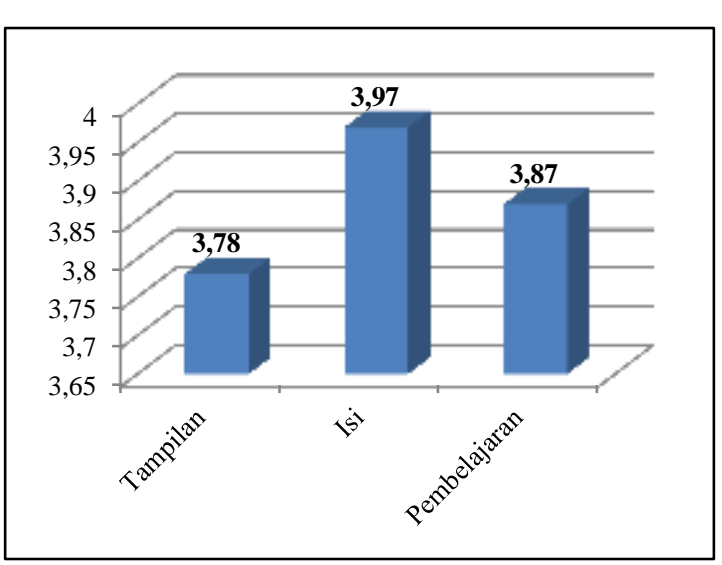

Gambar 4. Kualitas Produk Hasil Uji Coba LapanganAwal

Berdasarkan hasil uji coba lapangan awal dengan jumlah subjek 15 siswa kelas XI yang berasal dari 3 SMA Negeri Yogyakarta terhadap tiga aspek penilaian yakni tampilan, isi dan pembelajaran dapat disimpulkan bahwa media termasuk kriteria "Baik" dengan rerata skor 3,87 .

Uji coba lapangan utama, melibatkan 6 SMA Negeri yang ada di Kotamadya Yogyakarta dengan jumlah subjek 30 siswa. Adapun kualitas produk hasil uji coba lapangan utama sebagai berikut.

Tabel 5. Penilaian Uji Coba LapanganUtama

\begin{tabular}{cccc}
\hline No & Tes & $\begin{array}{c}\text { Jumlah Skor } \\
\text { Siswa }\end{array}$ & $\begin{array}{c}\text { Rata-rata } \\
\text { Skor Siswa }\end{array}$ \\
\hline 1 & Pretest & 166 & 5,53 \\
2 & Posttest & 227 & 7,56 \\
\multicolumn{3}{c}{ Selisih Skor } & $(+) 2,03$ \\
\hline
\end{tabular}

Dari hasil perhitugan rata-rata tingkat penguasaan materi siswa berkenaan dengan hasil nilai pretest adalah 5,53 dengan jumlah total skor 166. Setelah menggunakan media tingkat penguasaan materi siswa meningkat menjadi 7,56 dengan jumlah total skor 227. Selisih nilai pretest dan posttest adalah 2,03 poin. Diketahui bahwa terjadi peningkatan penguasaan materi HIV/AIDS sebelum dan sesudah diberikan media. Berikut ini gambar kualitas produk hasil uji coba lapangan awal.

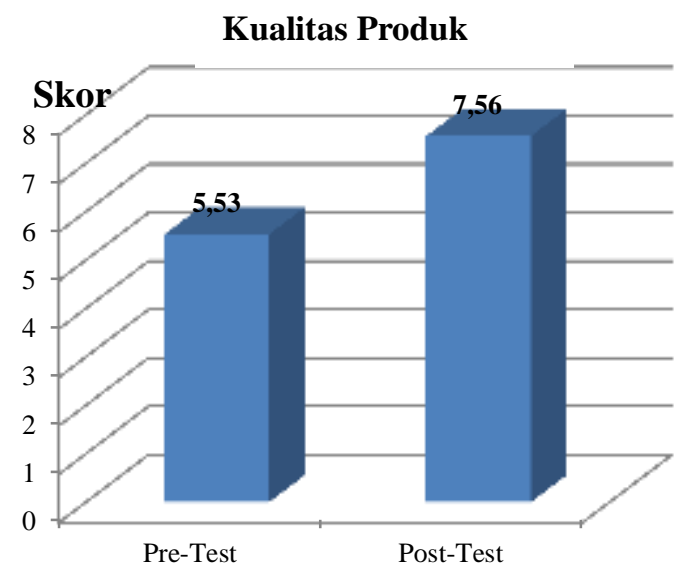

\section{Gambar 5. Kualitas Produk Hasil Uji Coba Lapangan Utama}

Uji operasional melibatkan seluruh SMA Negeri se-Kotamadya Yogyakarta yang berjumlah 11 sekolah dengan jumlah subjek 55 siswa. Penilaian siswa hasil uji coba operasional dan rerata skor yang diberikan untuk aspek tampilan, isi dan aspek pembelajaran lebih jelas dapat dilihat sebagai berikut. 
Tabel 6. Penilaian Hasil Uji Operasional

\begin{tabular}{clc}
\hline No & Aspek Penilaian & Rerata Skor Siswa \\
\hline 1 & Tampilan & 4,30 \\
2 & Isi & 4,21 \\
3 & Pembelajaran & 4,23 \\
Rata-rata Skor & $\mathbf{4 , 2 5}$ \\
Kriteria & SangatBaik \\
\hline
\end{tabular}

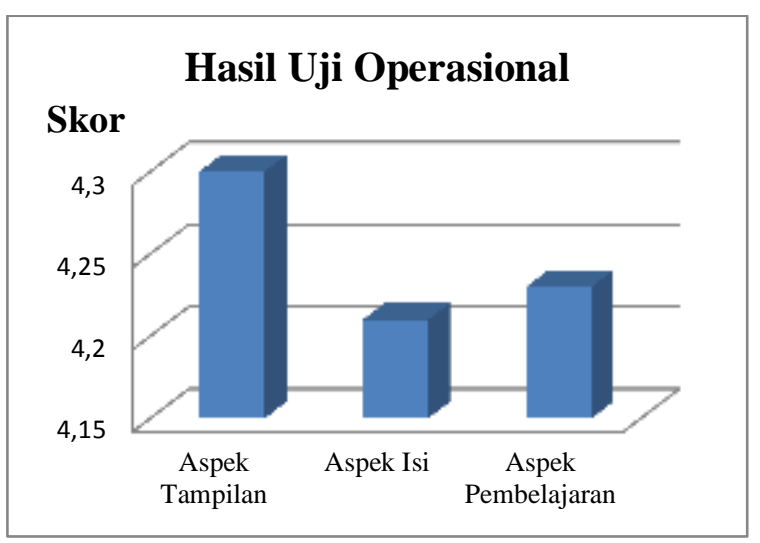

Gambar 6. Kualitas Produk Uji Operasional

Berdasarkan hasil uji coba operasional terhadap tiga aspek penilaian yakni tampilan, isi dan pembelajaran dapat disimpulkan bahwa media termasuk kriteria "Sangat Baik" dengan rerata skor 4,25.

Hasil akhir dari penelitian dan pengembangan ini adalah menghasilkan produk berupa CD Pembelajaran Penjasorkes materi HIV/ AIDS. Setelah melalui prosedur penelitian dan pengembangan produk yang dihasilkan diketahui kualitas dan efektifitasnya sehingga dapat digunakan sebagai salah satu sumber belajar di Sekolah khususnya bagi siswa kelas XI SMA. Tampilan produk akhir media pembelajaran dapat dilihat pada gambar berikut.

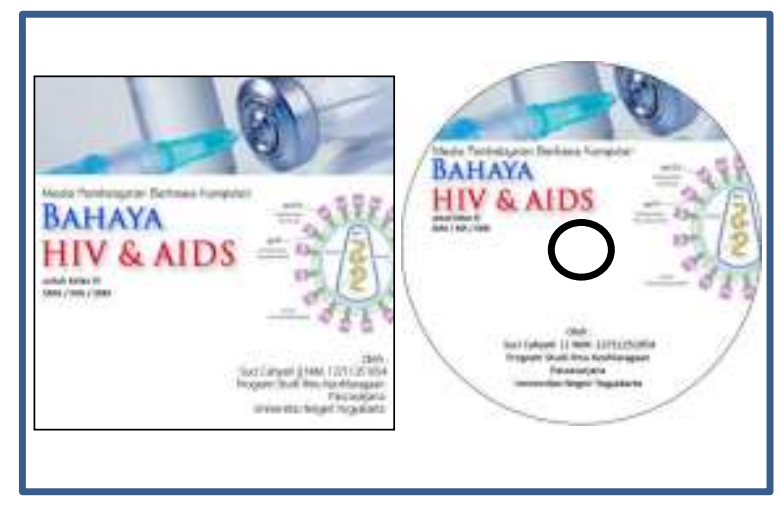

Gambar 7. Cover

\section{Simpulan dan Saran}

Simpulan

Produk akhir pengembangan media pembelajaran Pendidikan Jasmani Olahraga dan Kesehatan berbasis komputer ini berupa CD yang dilengkapi buku panduan. Produk ini setelah melalui tahapan pengembangan dinyatakan layak dan efektif digunakan dalam pembelajaran. Hal ini dapat dilihat berdasarkan hasil analisis validasi ahli dan uji coba lapangan sebagai berikut:

Ahli materi menilai dari aspek kualitas materi dan aspek isi. Diperoleh rerata 4,69 termasuk kategori sangat baik. Ahli media menilai dari aspek tampilan dan aspek pemrograman. Diperoleh rerata skor sebesar 4,02 termasuk kategori baik: (1) Penilaian siswa melalui uji coba lapangan awal, berdasarkan aspek tampilan, aspek isi dan aspek pembelajaran, diperoleh rerata skor sebesar 3,87 termasuk kategori baik; (2) Hasil pretest dan posttest siswa sebelum dan sesudah menggunakan media dan tes pilihan ganda, diperoleh rata-rata tingkat penguasaan materi siswa berkenaan dengan hasil nilai pretest adalah 5,53. Setelah menggunakan media terjadi peningkatan menjadi 7,56. Selisih nilai pretest dan posttest adalah 2,03 poin; (3) Penilaian siswa melalui uji operasional berdasarkan aspek tampilan, aspek isi, dan aspek pembelajaran, diperoleh rerata skor sebesar 4,25 termasuk kategori sangat baik.

Saran

Saran untuk pemanfaatan produk bagi guru mata pelajaran Penjasorkes diharapkan menggunakan produk ini sebagi contoh variasi produk media pembelajaran. Selain sebagai media belajar mandiri, produk ini juga digunakan dalam proses pembelajaran secara klasikal. Sosialisasi produk media pembelajaran ini juga diperlukan. Harapanya dapat membantu peran guru dalam proses pembelajaran dan dapat diaplikasikan pada semua jenjang pendidikan yang nantinya dapat dikembangkan lebih baik, lebih kreatif, dan lebih inovatif.

Diseminasi untuk pemanfaatan secara luas, produk ini dapat disosialisasikan kepada guru melalui sekolah dan siswa sebagai sumber belajar. Pengembangan produk lebih lanjut dapat dilakukan pada tema-tema pembelajaran penjasorkes lainya maupun pada pembelajaran ilmu lain. 


\section{DaftarPustaka}

Borg, W. R., \& Gall, M. D. (1983). Educational research (an introduction) 4th edition. New York \& London: Longman

Djamarah, S. B., \& Aswan, Z. (2002). Strategi belajar mengajar. Jakarta: Rineka Cipta.

Kemendiknas. (2013). Kurikulum 2013 kompetensi dasar sekolah menengah atas. Jakarta: Kemendiknas.

Lee, W. W., \& Owen, D. L. (2004). Multimedia based instructional design. San Fransisco: Pfeiffer.

Sadiman, A. S., dkk. (2006). Media pendidikan. Jakarta: PT Raja Grafindo Persada.
Sudjana, N., \& Ahmad, R. (2007). Media pengajaran. Bandung: Sinar Baru.

Sukintaka. (2001). Teori pendidikan jasmani. Solo: Esa Grafika.

Suprijono, A. (2009). Cooperative learning. Yogyakarta: Pustaka Belajar.

Sutopo, A. H. (2003). Multimedia interaktif dengan flash. Yogyakarta: Graha Ilmu.

W. Cates, Jr. \& G. S. Bowen. (July 1989). Education for aids prevention: not our only voluntary weapon. American Journal of Public Health: Vol. 79, No. 7, pp. 871-874. Diambil pada tanggal $14 \quad$ November 2013, http://ajph.aphapublications.org/doi/abs /10.2105/AJPH.79.7.871. 